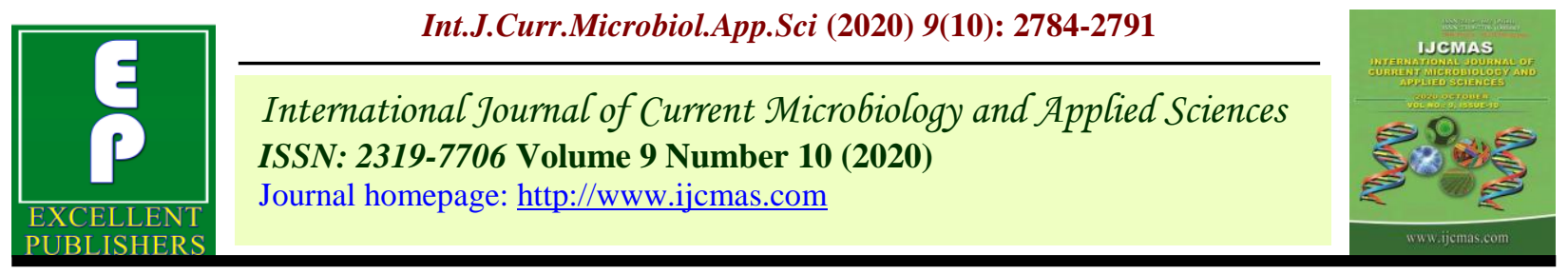

Original Research Article

https://doi.org/10.20546/ijcmas.2020.910.335

\title{
Effect of Levels of Phosphorus and Sulphur on Growth and Yield of Blackgram (Vigna mungo L.)
}

\author{
Richa Evelyn Singh*, Vikram Singh, Dhananjay Tiwari and Ashish Masih
}

Department of Agronomy, Naini Agricultural Institute, Sam Higginbottom University of Agriculture Technology and Sciences, Prayagraj-211007, Uttar Pradesh, India

\author{
*Corresponding author
}

\begin{tabular}{|l|}
\hline Ke y w o r d s \\
Phosphorus, \\
$\begin{array}{l}\text { Sulphur, Vigna } \\
\text { mungo, Yield }\end{array}$ \\
\hline Article Info \\
\hline $\begin{array}{l}\text { Accepted: } \\
\text { 20 September } 2020 \\
\text { Available Online: } \\
10 \text { October } 2020\end{array}$ \\
\hline \hline
\end{tabular}

\section{A B S T R A C T}

The present investigation titled "Effect of levels of phosphorous and sulphur on growth and yield of Blackgram (Vigna mungo L.)" was conducted at Crop Research Farm, Department of Agronomy, Naini Agricultural Institute, Sam Higginbottom University of Agriculture, Technology and Sciences, Prayagraj during zaid season of 2019. Shekhar-2 variety was selected for conducting the trial. The experiment was laid out in Randomized Block Design consisting of 9 treatments replicated thrice with the treatment combination of three levels of phosphorus viz., $\mathrm{P}_{1}-30 \mathrm{~kg} \mathrm{ha}^{-1}, \mathrm{P}_{2}-40 \mathrm{~kg} \mathrm{ha}^{-1}, \mathrm{P}_{3^{-}} 50 \mathrm{~kg} \mathrm{ha}^{-1}$ and three levels of sulphur viz., $\mathrm{S}_{1^{-}} 20 \mathrm{~kg} \mathrm{ha}^{-1}, \mathrm{~S}_{2^{-}} 25 \mathrm{~kg} \mathrm{ha}^{-1}, \mathrm{~S}_{3^{-}} 30 \mathrm{~kg} \mathrm{ha}^{-1}$. The results revealed that the treatment $\mathrm{T}_{6}\left(\mathrm{P}\right.$ at $40 \mathrm{~kg} \mathrm{ha}^{-1}+\mathrm{S}$ at $30 \mathrm{~kg} \mathrm{ha}^{-1}$ ) recorded maximum plant height $(32.77 \mathrm{~cm})$, number of nodules per plant $(18.56)$, dry weight $\left(11.92 \mathrm{~g} \mathrm{plant}^{-1}\right)$, Crop Growth rate (CGR) $\left(0.703 \mathrm{~g} \mathrm{~m}^{-2} \mathrm{day}^{-1}\right)$, number of pods per plant $(24.51)$, number of grains per pod (6.40), test weight $(47.60 \mathrm{~g})$, grain yield $\left(2.76 \mathrm{t} \mathrm{ha}^{-1}\right)$ and protein content $(24.28 \%)$. However, the maximum stover yield $\left(6.22 \mathrm{t} \mathrm{ha}^{-1}\right)$ was obtained with the treatment $\mathrm{T}_{5}(\mathrm{P}$ at $40 \mathrm{~kg} \mathrm{ha}^{-1}+\mathrm{S}$ at $25 \mathrm{~kg} \mathrm{ha}^{-1}$ ). Maximum gross return ( $₹ 124200 \mathrm{ha}^{-1}$ ), net return ( $₹ 82422.58$ $\mathrm{ha}^{-1}$ ) and $\mathrm{B}: \mathrm{C}$ ratio (2.97) was recorded with the treatment $\mathrm{T}_{6}\left(\mathrm{P}\right.$ at $40 \mathrm{~kg} \mathrm{ha}^{-1}+\mathrm{S}$ at $30 \mathrm{~kg}$ $\left.\mathrm{ha}^{-1}\right)$.

\section{Introduction}

The word "pulse" is derived from the Latin word "puls" means pottage, i.e. seed boiled to make porridge or thick soup (Patel, 2017). Pulses, also known as grain legumes are secondary to cereals in production and consumption in India. They are found to contain low fat, low sodium, high fibre, no cholesterol and are a good source of protein, minerals, various vitamins and amino acids. Pulses provide $25 \%$ of protein requirements of predominantly vegetarian population. The
World Health Organisation (WHO) recommends a per capita consumption of pulses at 80 gram per day and the Indian Council of Medical Research (ICMR) has recommended a minimum consumption of 47 g. Pulse crops are one of the most sustainable crops a farmer can grow. Pulses are less water requiring crop, prevent soil erosion due to their deep root system, give good ground coverage, fit well in crop rotation and crop mixtures and fix atmospheric nitrogen through symbiosis. These crops have the ability to reduce atmospheric nitrogen to 
usable form through biological nitrogen fixation (BNF) in association with root nodule bacteria. Blackgram (Vigna mungo L.) commonly known as urdbean is a deep rooted drought hardy crop. It is a self-pollinated leguminous crop which contains $24 \%$ protein, $60 \%$ carbohydrate, $1.3 \%$ fat, $3.2 \%$ minerals, $0.9 \%$ fibre, $154 \mathrm{mg}$ calcium, $385 \mathrm{mg}$ phosphorus and $9.1 \mathrm{mg}$ iron. It is rich in vitamin $\mathrm{A}, \mathrm{B}_{1}, \mathrm{~B}_{3}$ and has small amount of thiamine, riboflavin, niacin and vitamin $\mathrm{C}$ in it. It contains $78 \%$ to $80 \%$ nitrogen in the form of albumin and globulin. The dry seeds are good source of phosphorus. After removing pods, its plant may be used as good quality green or dry fodder or green manure. It can be grown on all type of soils ranging from sandy loam to heavy clay except alkaline and saline.

In India, 44.93 lakh hectare area is under blackgram cultivation with a total production of 29.26 lakh tonnes. (Directorate of Pulse development, Annual report 2016-17). Agricultural feasibility and economic viability of blackgram as sole as well as intercrop in crop sequences have been established due to unique property of maintaining and restoring soil fertility through biological nitrogen fixation as well as conserving and improving physical properties of soil by virtue of its deep root system and leaf fall.

Despite of these features, the productivity of this crop is below the average owing to several constraints. The major reason for the low productivity of black gram in the country, apart from natural constraints, is due to supply imbalance use of nutrients. Proper fertilization is essential to improve the productivity of blackgram. It can meet its nitrogen requirements by symbiotic fixation of atmospheric nitrogen. The nutrients which need attention are phosphorus and sulphur.

Phosphorus plays a key role in photosynthesis, metabolism of sugars, energy storage and transfer, cell division, cell enlargement, transfer of genetic information, root growth, nodulation and nitrogen fixation in plants. Increase in yield brought by $P$ application is significant and economically viable owing to its wide spread deficiency in soils of India in general. It also plays an important role in the process of photosynthesis, energy conservation and transportation, cell division and meristematic growth in living tissues, grain quality and most of physico-bio-chemical activities. Accordingly, 80 percent of the soils in India need $\mathrm{P}$ application at recommended rates, whereas, the application of some quantity of $\mathrm{P}$ fertilizers would be essential to arrest $\mathrm{P}$ mining from the soils so as to sustain high yield of crops.

Sulphur is another important essential plant nutrient. Involvement of sulphur in plants metabolism and yield responses makes sulphur as the fourth major element after nitrogen, phosphorus and potassium. Sulphur plays an important role in physiological processes like synthesis of sulphur containing amino acids (cystine and methionine) and Chlorophyll. It is also responsible for synthesis of certain vitamins (biotine and thiamine), co-enzyme-A, metabolism of carbohydrates, fat and protein. Sulphur also promotes nodulation in legumes. In this way, sulphur can be very helpful in enhancing the productivity of pulses including urdbean. Wide spread $\mathrm{S}$ deficiency have been observed on larger areas due to use of high analysis $S$ free fertilizers like urea and diammonium phosphate (DAP) in high yielding varieties and intensive cropping, and is more conspicuous in light textured soils low in organic matter (Prajapati et al., 2013). Phosphorus fertilizer application results in increased of anion adsorption sites by phosphate, which releases sulphate ions into the soil solution (Tiwari and Gupta, 2006). 
Thus, it may be subjected to leaching if not taken up by plant roots. Studies have indicated both synergistic and antagonistic relationship between sulphur and phosphorus but their relationship depends on their rate of application and crop species. The interaction of these nutrient elements may affect the critical levels of available phosphorus and sulphur below which response to their application could be observed. Information on effect of combined application of $\mathrm{P}$ and $\mathrm{S}$ on yield, quality and content of each nutrient in black gram is rather limited. Hence the present investigation titled "Effect of levels of phosphorous and sulphur on growth and yield of Blackgram (Vigna mungo L.)" was conducted.

\section{Materials and Methods}

Field experiment was conducted during zaid season of 2019 at Crop Research Farm, Department of Agronomy, Naini Agricultural Institute, Sam Higginbottom University of Agriculture, Technology and Sciences, Prayagraj. Shekhar-2 variety was selected for conducting the trial. Total 9 treatment combination comprising of three levels of phosphorus viz., $\mathrm{P}_{1}-30 \mathrm{~kg} \mathrm{ha}^{-1}, \mathrm{P}_{2}-40 \mathrm{~kg}$ ha , $\mathrm{P}_{3-5} 50 \mathrm{~kg} \mathrm{ha}^{-1}$ and three levels of sulphur viz., $\mathrm{S}_{1-} 20 \mathrm{~kg} \mathrm{ha}^{-1}, \mathrm{~S}_{2-} 25 \mathrm{~kg} \mathrm{ha}^{-1}, \mathrm{~S}_{3}-30 \mathrm{~kg}$ $\mathrm{ha}^{-1}$ were evaluated in Randomized Block Design with three replications. The soil of the experimental plot was Sandy loam in texture having medium to good drainage, EC $0.27 \mathrm{dS}$ $\mathrm{m}^{-1}$, and soil $\mathrm{pH}$ 7.4. The chemical analysis of soil revealed the following values - organic carbon was estimated to be $0.32 \%$, nitrogen $188.3 \mathrm{~kg} \mathrm{ha}^{-1}$, phosphorus $34.5 \mathrm{~kg} \mathrm{ha}^{-1}$, potassium $87 \mathrm{~kg} \mathrm{ha}^{-1}$ and sulphur $14.74 \mathrm{ppm}$. Blackgram variety "Shekhar- 2" seeds were sown at $30 \mathrm{~cm} \times 15 \mathrm{~cm}$ spacing according to the seed rate of $30 \mathrm{~kg} \mathrm{ha}^{-1}$.

The recommended dose of nitrogen $\left(20 \mathrm{~kg} \mathrm{ha}^{-}\right.$ $\left.{ }^{1}\right)$ and potassium $\left(20 \mathrm{~kg} \mathrm{ha}^{-1}\right)$ was applied as basal dose just before sowing and phosphorus and sulphur were applied as per the treatments. Urea, DAP, MoP and Sulphur powder were taken as fertilizer sources for $\mathrm{N}, \mathrm{P}, \mathrm{K}$ and $\mathrm{S}$ respectively.

\section{Results and Discussion}

\section{Growth attributes}

Data presented in Table 1 shows effect of levels of phosphorus and sulphur on growth attributes of Blackgram such as plant height, number of nodule, plant dry weight, crop growth rate (CGR) and relative growth rate (RGR). Among different phosphorus and sulphur levels, the highest values were recorded with the application of $\mathrm{P}$ at $40 \mathrm{~kg} \mathrm{ha}^{-}$ ${ }^{1}$ along with $\mathrm{S}$ at $30 \mathrm{~kg} \mathrm{ha}^{-1}$. The interactive effect of phosphorus and sulphur significantly influenced all the growth parameters except RGR. The results revealed that the treatment $\mathrm{T}_{6}\left(\mathrm{P}\right.$ at $40 \mathrm{~kg} \mathrm{ha}^{-1}+\mathrm{S}$ at $30 \mathrm{~kg} \mathrm{ha}^{-1}$ ) recorded maximum plant height $(32.77 \mathrm{~cm})$, number of nodules per plant (18.56), dry weight (11.92 g plant $\left.^{-1}\right)$ and Crop Growth rate $\left(0.703 \mathrm{~g} \mathrm{~m}^{-2}\right.$ day $\left.^{-1}\right)$. Increased plant growth might be due to better nutritional environment in root zone. Phosphorus is a vital component of ADP and ATP and it plays an important role in conservation and transfer of energy in metabolic reaction. It also stimulates cell division resulting in increased growth of plants and also improves nodulation and $\mathrm{N}$ fixation by roots. Increased growth of plants leads to higher plant dry weight. With increasing levels of phosphorus, the response of sulphur also increased significantly. Sulphur availability results in better formation of nodule, nitrogenase enzyme, chlorophyll etc and thereby influencing growth components of the crop. The results are similar to the findings of Yadav et al., (2017), Niraj and Prakash (2015), Mir et al., (2013), Chettri and Mondal (2004) and Kumar et al., (2000). 
Table.1 Effect of levels of phosphorus and sulphur on growth attributes of Blackgram

\begin{tabular}{|c|c|c|c|c|c|c|}
\hline \multirow[b]{2}{*}{$\begin{array}{l}\text { Treatment } \\
\text { No. }\end{array}$} & \multicolumn{6}{|c|}{60 Days after sowing } \\
\hline & Treatments combination & $\begin{array}{l}\text { Plant height } \\
\quad(\mathrm{cm})\end{array}$ & $\begin{array}{c}\text { Number of } \\
\text { Nodules } \\
{ }^{-1} \\
\text { plant }\end{array}$ & $\begin{array}{c}\text { Dry weight } \\
\text { (g) }\end{array}$ & $\begin{array}{l}\text { Crop growth rate } \\
\text { 45-60 DAS } \\
\left(\mathrm{g} \mathrm{m}^{-2} \text { day }^{-1}\right)\end{array}$ & $\begin{array}{c}\text { Relative growth } \\
\text { rate } 45-60 \text { DAS } \\
-1{ }^{-1} \\
\left(\mathrm{mg} \mathrm{g}^{\text {day }}\right)\end{array}$ \\
\hline 1 & $\mathrm{P}_{1}+\mathrm{S}_{1}: 30 \mathrm{~kg} \mathrm{ha}^{-1}+20 \mathrm{~kg} \mathrm{ha}^{-1}$ & 25.50 & 7.33 & 3.70 & 0.172 & 0.085 \\
\hline 2 & $\mathrm{P}_{1}+\mathrm{S}_{2}: 30 \mathrm{~kg} \mathrm{ha}^{-1}+25 \mathrm{~kg} \mathrm{ha}^{-1}$ & 26.07 & 8.67 & 3.89 & 0.196 & 0.098 \\
\hline 3 & $\mathrm{P}_{1}+\mathrm{S}_{3}: 30 \mathrm{~kg} \mathrm{ha}^{-1}+30 \mathrm{~kg} \mathrm{ha}^{-1}$ & 26.73 & 8.89 & 5.36 & 0.295 & 0.111 \\
\hline 4 & $\mathrm{P}_{2}+\mathrm{S}_{1}: 40 \mathrm{~kg} \mathrm{ha}^{-1}+20 \mathrm{~kg} \mathrm{ha}^{-1}$ & 27.04 & 8.33 & 6.63 & 0.344 & 0.112 \\
\hline 5 & $\mathrm{P}_{2}+\mathrm{S}_{2}: 40 \mathrm{~kg} \mathrm{ha}^{-1}+25 \mathrm{~kg} \mathrm{ha}^{-1}$ & 28.40 & 14.11 & 8.39 & 0.478 & 0.141 \\
\hline 6 & $\mathrm{P}_{2}+\mathrm{S}_{3}: 40 \mathrm{~kg} \mathrm{ha}^{-1}+30 \mathrm{~kg} \mathrm{ha}^{-1}$ & 32.77 & 18.56 & 11.92 & 0.703 & 0.143 \\
\hline 7 & $\mathrm{P}_{3}+\mathrm{S}_{1}: 50 \mathrm{~kg} \mathrm{ha}^{-1}+20 \mathrm{~kg} \mathrm{ha}^{-1}$ & 26.50 & 10.67 & 5.07 & 0.280 & 0.103 \\
\hline 8 & $\mathrm{P}_{3}+\mathrm{S}_{2}: 50 \mathrm{~kg} \mathrm{ha}^{-1}+25 \mathrm{~kg} \mathrm{ha}^{-1}$ & 27.50 & 10.22 & 7.67 & 0.424 & 0.113 \\
\hline \multirow[t]{4}{*}{9} & $\mathrm{P}_{3}+\mathrm{S}_{3}: 50 \mathrm{~kg} \mathrm{ha}^{-1}+30 \mathrm{~kg} \mathrm{ha}^{-1}$ & 28.07 & 11.22 & 8.15 & 0.470 & 0.128 \\
\hline & F- test & $\mathrm{S}$ & $\mathrm{S}$ & $\mathrm{S}$ & $\mathrm{S}$ & NS \\
\hline & S. Ed. $( \pm)$ & 1.025 & 3.264 & 2.084 & 0.135 & 0.028 \\
\hline & $\mathrm{CD}(\mathrm{P}=0.05)$ & 2.173 & 6.919 & 4.419 & 0.286 & - \\
\hline
\end{tabular}


Table.2 Effect of levels of phosphorus and sulphur on yield attributes and protein content of Blackgram

\begin{tabular}{|c|c|c|c|c|c|c|c|}
\hline \multirow[b]{2}{*}{$\begin{array}{c}\text { Treatmen } \\
\mathbf{t} \\
\text { No. }\end{array}$} & \multicolumn{7}{|c|}{ At Harvest } \\
\hline & $\begin{array}{l}\text { Treatments } \\
\text { combination }\end{array}$ & $\begin{array}{c}\text { Number } \\
\text { of Pods } \\
{ }^{-1} \\
\text { plant }\end{array}$ & $\begin{array}{c}\text { Number } \\
\text { of grains } \\
\text { Pod }^{-1}\end{array}$ & $\begin{array}{c}\text { Test } \\
\text { weight } \\
(\mathrm{g})\end{array}$ & $\begin{array}{l}\text { Grain } \\
\text { yield } \\
\left(\mathrm{t} \mathrm{ha}^{-1}\right)\end{array}$ & $\begin{array}{l}\text { Stover } \\
\text { yield } \\
\left(\mathrm{t} \mathrm{ha}^{-1}\right)\end{array}$ & $\begin{array}{c}\text { Protein } \\
\text { content } \\
(\%)\end{array}$ \\
\hline 1 & $\mathrm{P}_{1}+\mathrm{S}_{1}: 30 \mathrm{~kg} \mathrm{ha}^{-1}+20 \mathrm{~kg} \mathrm{ha}^{-1}$ & 16.44 & 3.55 & 32.60 & 1.62 & 5.13 & 18.07 \\
\hline 2 & $\mathrm{P}_{1}+\mathrm{S}_{2}: 30 \mathrm{~kg} \mathrm{ha}^{-1}+25 \mathrm{~kg} \mathrm{ha}^{-1}$ & 18.57 & 4.78 & 37.09 & 1.62 & 5.21 & 18.99 \\
\hline 4 & $\mathrm{P}_{2}+\mathrm{S}_{1}: 40 \mathrm{~kg} \mathrm{ha}^{-1}+20 \mathrm{~kg} \mathrm{ha}^{-1}$ & 19.27 & 5.06 & 39.83 & 1.88 & 5.65 & 19.18 \\
\hline 5 & $\mathrm{P}_{2}+\mathrm{S}_{2}: 40 \mathrm{~kg} \mathrm{ha}^{-1}+25 \mathrm{~kg} \mathrm{ha}^{-1}$ & 23.48 & 5.94 & 44.78 & 2.52 & 6.22 & 22.67 \\
\hline 6 & $\mathrm{P}_{2}+\mathrm{S}_{3}: 40 \mathrm{~kg} \mathrm{ha}^{-1}+30 \mathrm{~kg} \mathrm{ha}^{-1}$ & 24.51 & 6.40 & 47.60 & 2.76 & 6.08 & 24.28 \\
\hline 7 & $\mathrm{P}_{3}+\mathrm{S}_{1}: 50 \mathrm{~kg} \mathrm{ha}^{-1}+20 \mathrm{~kg} \mathrm{ha}^{-1}$ & 22.17 & 5.60 & 40.87 & 2.09 & 5.96 & 22.48 \\
\hline \multirow{2}{*}{9} & S. Ed. $( \pm)$ & 0.892 & 0.486 & 3.532 & 0.323 & 0.294 & - \\
\hline & $\mathrm{CD}(\mathrm{P}=0.05)$ & 1.890 & 1.030 & 7.488 & 0.685 & 0.623 & - \\
\hline
\end{tabular}


Table.3 Effect of levels of phosphorus and sulphur on economics of blackgram

\begin{tabular}{|c|c|c|c|c|c|}
\hline $\begin{array}{c}\text { Treatment } \\
\text { No. }\end{array}$ & $\begin{array}{l}\text { Treatments } \\
\text { combination }\end{array}$ & $\begin{array}{c}\text { Cost of } \\
\text { Cultivation } \\
\left(₹ \text { ha }^{-1}\right)\end{array}$ & $\begin{array}{c}\text { Gross return } \\
\text { (₹ ha }^{-1} \text { ) }\end{array}$ & $\begin{array}{c}\text { Net Return } \\
\left(₹ \text { ha }^{-1}\right)\end{array}$ & B:C ratio \\
\hline 1 & $\mathrm{P}_{1}+\mathrm{S}_{1}: 30 \mathrm{~kg} \mathrm{ha}^{-1}+20 \mathrm{~kg} \mathrm{ha}^{-1}$ & 40216.32 & 72900 & 32683.68 & 1.81 \\
\hline 2 & $\mathrm{P}_{1}+\mathrm{S}_{2}: 30 \mathrm{~kg} \mathrm{ha}^{-1}+25 \mathrm{~kg} \mathrm{ha}^{-1}$ & 40866.32 & 72900 & 32033.68 & 1.78 \\
\hline 3 & $\mathrm{P}_{1}+\mathrm{S}_{3}: 30 \mathrm{~kg} \mathrm{ha}^{-1}+30 \mathrm{~kg} \mathrm{ha}^{-1}$ & 41516.32 & 85500 & 43983.68 & 2.06 \\
\hline 4 & $\mathrm{P}_{2}+\mathrm{S}_{1}: 40 \mathrm{~kg} \mathrm{ha}^{-1}+20 \mathrm{~kg} \mathrm{ha}^{-1}$ & 40477.42 & 84600 & 44122.58 & 2.09 \\
\hline 5 & $\mathrm{P}_{2}+\mathrm{S}_{2}: 40 \mathrm{~kg} \mathrm{ha}^{-1}+25 \mathrm{~kg} \mathrm{ha}^{-1}$ & 41127.42 & 113400 & 72272.58 & 2.76 \\
\hline 6 & $\mathrm{P}_{2}+\mathrm{S}_{3}: 40 \mathrm{~kg} \mathrm{ha}^{-1}+30 \mathrm{~kg} \mathrm{ha}^{-1}$ & 41777.42 & 124200 & 82422.58 & 2.97 \\
\hline 7 & $\mathrm{P}_{3}+\mathrm{S}_{1}: 50 \mathrm{~kg} \mathrm{ha}^{-1}+20 \mathrm{~kg} \mathrm{ha}^{-1}$ & 40738.52 & 94050 & 53311.48 & 2.31 \\
\hline 8 & $\mathrm{P}_{3}+\mathrm{S}_{2}: 50 \mathrm{~kg} \mathrm{ha}^{-1}+25 \mathrm{~kg} \mathrm{ha}^{-1}$ & 41388.52 & 108900 & 67511.48 & 2.63 \\
\hline 9 & $\mathrm{P}_{3}+\mathrm{S}_{3}: 50 \mathrm{~kg} \mathrm{ha}^{-1}+30 \mathrm{~kg} \mathrm{ha}^{-1}$ & 42038.52 & 96750 & 54711.48 & 2.30 \\
\hline
\end{tabular}




\section{Yield and quality attributes}

Observations regarding the response of different levels of phosphorus and sulphur on yield attributes and protein content of Blackgram are presented in Table 2.

The data shows that the phosphorus and sulphur significantly influenced all the yield parameters. Among different phosphorus and sulphur levels, the highest number of pods per plant (24.51), number of grains per pod (6.40), test weight $(47.60 \mathrm{~g})$, grain yield (2.76 $\left.\mathrm{t} \mathrm{ha}^{-1}\right)$ and protein content $(24.28 \%)$ was recorded with the application of $\mathrm{P}$ at 40 $\mathrm{kg} \mathrm{ha}^{-1}$ along with $\mathrm{S}$ at $30 \mathrm{~kg} \mathrm{ha}^{-1}$. However, the maximum stover yield $\left(6.22 \mathrm{t} \mathrm{ha}^{-1}\right)$ was obtained with the treatment $\mathrm{T}_{5}$ consisting of $\mathrm{P}$ at $40 \mathrm{~kg} \mathrm{ha}^{-1}$ along with $\mathrm{S}$ at $25 \mathrm{~kg} \mathrm{ha}^{-1}$.

The yield attributes were significantly influenced due to better availability of nutrients in the soil. $\mathrm{P}_{2} \mathrm{O}_{5}$ increased the photosynthetic activity of plant which ultimately led to effective assimilate partitioning of photosynthates from sources to sink in post flowering stage. It also led to the development of extensive root system which increased the water and mineral extraction capacity of plants resulting in better plant growth and yield. This finding was similar to results obtained by Kokani et al., (2014) and Thesiya et al., (2013). Sulphur is a part of amino acid (Cystine), which helps in chlorophyll formation, photosynthetic process, activation of enzymes and higher grain yield. More availability of sulphur during vegetative and reproductive stages of the crop boosted the crop yield. The results were in relation with the findings of Mitra et al., (2006) and Singh et al., (2017).

The response to applied phosphorus with respect to protein content in blackgram is attributed to more nitrogen fixation. Similar results were also reported by Kumawat et al.,
(2004). Favourable influence of sulphur on protein content was due to synthesis of sulphur containing amino acids and nitrogen uptake. The results were in conformity with Mir et al., (2013).

\section{Economics of treatment}

Economic evaluation of the treatments was done on the basis of gross return, net return and benefit: cost ratio (Table 3). It was observed that the treatment receiving $\mathrm{P}$ at 40 $\mathrm{kg} \mathrm{ha}^{-1}$ along with $\mathrm{S}$ at $30 \mathrm{~kg} \mathrm{ha}^{-1}$ registered highest gross return (₹124200 ha ${ }^{-1}$ ), net return (₹82422.58 ha ${ }^{-1}$ ) and benefit cost ratio (2.97). This might be due to higher yield in this treatment compared to other treatments.

It is concluded that in the experiment on Blackgram, the treatment number 6 in which Phosphorus was applied at $40 \mathrm{~kg} \mathrm{ha}^{-1}$ along with Sulphur at $30 \mathrm{~kg} \mathrm{ha}^{-1}$ recorded higher growth [like plant height $(32.77 \mathrm{~cm})$, number of nodules per plant (18.56), dry weight $\left(11.9235 \mathrm{~g} \mathrm{plant}^{-1}\right.$ and Crop Growth rate $\left(0.703 \mathrm{~g} \mathrm{~m}^{-2}\right.$ day $\left.\left.^{-1}\right)\right]$ and yield attributes (namely number of pods per plant (24.51), number of grains per pod (6.40), test weight $(47.60 \mathrm{~g})$, grain yield $\left(2.76 \mathrm{t} \mathrm{ha}^{-1}\right)$ and protein content (24.28\%)) with highest Net Returns (₹ 82422.58 ha ${ }^{-1}$ ) and B:C ratio (2.97).

\section{Acknowledgement}

The authors are grateful to the teaching and non-teaching staff of Naini Agricultural Institute, Sam Higginbottom University of Agriculture, Technology and Sciences, Prayagraj, Uttar Pradesh for their support during this study.

\section{References}

Chettri, M. and Mondal, S.S. 2004. Response of blackgram to different levels of potassium and sulphur under irrigated 
and non irrigated condition. Legume Research 27(4): 265-269.

Himani B. Patel, K.A. Shah, M.M. Barvaliya and Patel, S.A. 2017. Response of Greengram (Vigna radiata L.). To Different Level of Phosphorus and Organic Liquid Fertilizer. Int.J.Curr.Microbiol.App.Sci. 6 (10): 3443-3451.

Kokani, J.M., Shah, K.A., Tandel, B.M. and Nayaka, P. (2014). Growth, yield attributes and yield of summer blackgram (Vigna mungo L.) as influenced by FYM, phosphorus and sulphur. An international quarterly $J$. of Environ. Sci. 429-433:2014.

Kumar, K., Verma, A.K. and Srivastava, G.P. 2000. Yield attributing characters and grain yield of urdbean (Vigna mungo L. Helpper) as influenced by levels of phosphate. Journal of Research Birsa Agriculture University 12: 233-234.

Kumawat, B.L., Pathan, A.R.K. and Chahan, R. (2004). Response of taramirra to sulphur and phosphorus application on Typic Pasmmnt. J. Indian Soc. Soil Sci., 52: 476-478.

Mir, A. H., Lal, S. B., Salmani, M., Abid, M. and Khan, I. 2013. Growth, yield and nutrient content of blackgram (Vigna mungo) as influenced by levels of phosphorus, sulphur and phosphorus solubilizing bacteria, SAARC Journal of Agriculture, 11(1): 1-6.

Mitra AK, Banerjee K, Pal AK. Effect of different levels of phosphors and sulphur on yield, protein content of seed and economics of summer greengram.

Research on crop. 2006; 7 (2): 404-405.

Niraj, V.P.S. and Prakash, V. (2015). Influences of phosphorus and sulphur on, yield and quality of blackgram (Pysiolus mungo L.). Journal of AgriSearch 2 (4): 269-272.

Prajapati J. P., Kumar S., Singh R. P., Kushwaha I. K., Yadav P. K. (2013). Effect of Phosphorus and Sulfur on Growth, Yield Attributes and Yield of Green Gram (Vigna radiata L.). Environment \& Ecology 31 (4A): 1977-1979.

Singh, D.P. (2017). Effect of potassium and sulphur on performance of green gram (Vigna radiate) in alluvial soil. Annals of Plant and Soil Research 19 (2): 223226.

Thesiya, N.M. Chovatia, P.K. and Kikani, V.L. (2013) Effect of potassium and sulphur on growth and yield of blackgram. Legume Res, 63 (3):255258, 2013.

Tiwari, K.N. and Gupta, B.R. (2006). Sulphur for sustainable high yield agriculture in Uttar Pradesh. Indian J. Fert., 1 (11): 37-52.

Yadav, M., Yadav, S.S., Kumar, S., Yadav, T. and Yadav, H.K. (2017). Effect of phosphorus and bio-fertilizers on growth and yield of urdbean [Vigna mungo (L.) Hepper]. Int. J. of Plant and Soil Sci., 18 (5):1-7.

\section{How to cite this article:}

Richa Evelyn Singh, Vikram Singh, Dhananjay Tiwari and Ashish Masih. 2020. Effect of Levels of Phosphorus and Sulphur on Growth and Yield of Blackgram (Vigna mungo L.). Int.J.Curr.Microbiol.App.Sci. 9(10): 2784-2791. doi: https://doi.org/10.20546/ijcmas.2020.910.335 